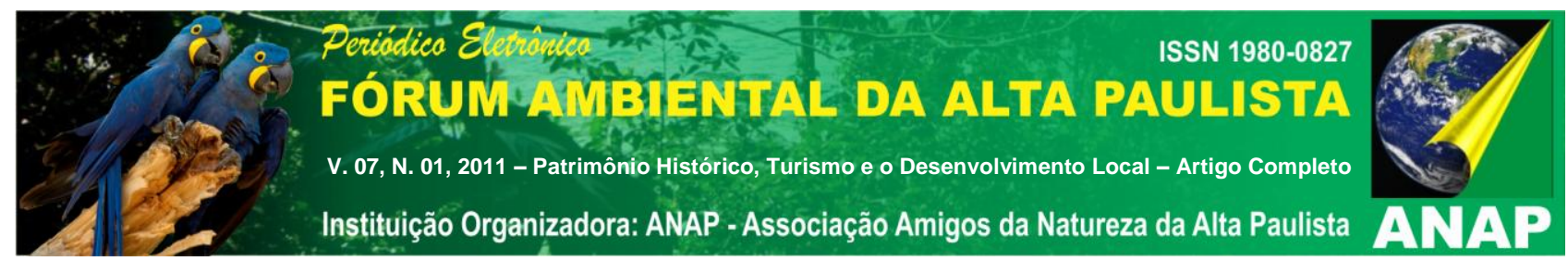

\title{
PATRIMÔNIO HISTÓRICO, TURISMO E EDUCAÇÃO: FAZENDAS MANDAGUAHY E SANTO ANTONIO DO YPÊS - JAÚ - SP
}

\author{
Guilherme E. A. Prado de Castro Valente ${ }^{1}$
}

Oriowaldo Queda ${ }^{2}$

\begin{abstract}
RESUMO: O artigo descreve a trajetória da criação de mecanismos de preservação do patrimônio histórico da cidade de Jaú, Estado de São Paulo, e sobre as ações do poder municipal para tornar o patrimônio histórico em atrativo turístico. Analisa como foi a transformação do patrimônio natural e edificado em produto de turismo cultural nas fazendas Santo Antonio dos Ypês e Mandaguahy, através de bibliografia, periódicos locais, dissertação de mestrado e programas educativos das fazendas. Conclui que a educação para a cidadania, consciente da importância da conservação e a apropriação do patrimônio formará público consumidor de turismo cultural que contribuirá para a valorização de sítios históricos, viabilizando-os financeiramente através de taxas de visitação para sua conservação e servindo de incentivo aos proprietários que os conservam.
\end{abstract}

Palavras chave: Patrimônio histórico. Turismo. Educação.

\section{INTRODUÇÃO}

O Brasil ao longo de seus mais de quinhentos anos de história é marcado pela existência de edificações e relatos que formam nosso patrimônio material e imaterial. No que tange ao patrimônio material há inúmeros exemplares de construções ou ruínas de norte ao sul do país. Este legado foi sendo aos poucos valorizado através de leis de proteção federais, estaduais e municipais. Cada uma, na sua esfera de importância,

\footnotetext{
${ }^{1}$ Mestre em desenvolvimento regional e meio ambiente. Professor na Faculdade do Interior Paulista, Barra Bonita, SP

${ }^{2}$ Professor titular aposentado, Esalq/USP e docente do Mestrado em Desenvolvimento Regional e Meio Ambiente/UNIARA
} 


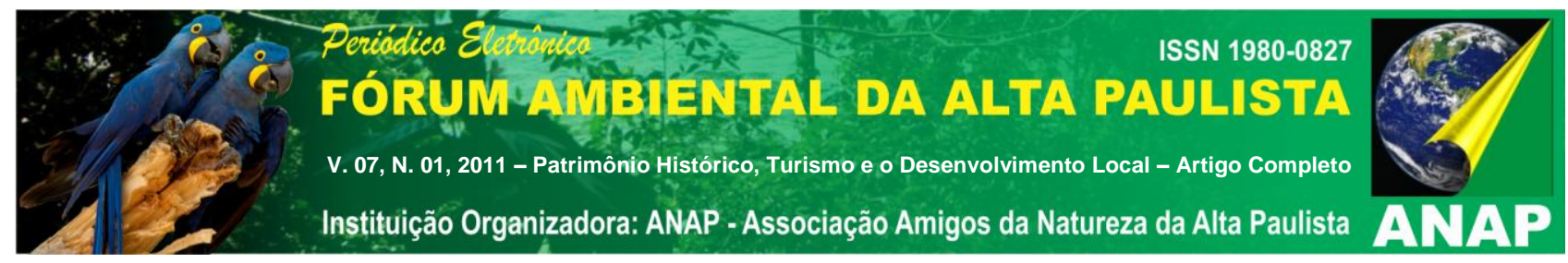

preserva ou impede a demolição de exemplares da arquitetura brasileira importantes para a nação, estado ou município. As decisões de preservação tem sido, em boa parte desta trajetória, propostas no âmbito do poder executivo e legislativo sem a participação direta das comunidades onde estes bens estão localizados.

São raros os exemplos em que a própria comunidade se organiza em função da preservação. Mais recentemente tivemos os exemplos das cidades de Goiás Velho, Estado de Goiás, e São Luiz do Paraitinga, Estado de São Paulo, ambas reconhecidas como patrimônios históricos e parcialmente destruídas por inundações. Goiás Velho, que já era tombada pelo governo federal, teve um movimento popular para se adequar e ser reconhecida pela UNESCO como Patrimônio da Humanidade em 2001. A população de São Luiz do Paraitinga se empenhou na reconstrução de sua Matriz e do casario destruídos. Foi reconhecida como patrimônio histórico nacional somente após a enchente de 2010.

As duas cidades tombadas têm como característica comum a arquitetura tradicional brasileira com casas alinhadas à rua, telhados de duas águas e janelas tipo guilhotina. Este tipo de arquitetura foi valorizado pelo governo de Getúlio Vargas com a criação do Instituto do Patrimônio Histórico e Artístico Nacional em 1937. Segundo os idealizadores da criação do órgão preservacionista, este tipo de arquitetura representaria a unidade nacional uma vez que ela ocorre de norte ao sul do Brasil.

Se durante um período longo da história das edificações nacionais a arquitetura tradicional imperou quase que absoluto, a partir da segunda metade do século XIX com o enriquecimento do país por conta do aumento das exportações de café, popularizou-se as construções em estilo neoclássico e posteriormente em estilo eclético. A cidade de São Paulo foi quase que toda reconstruída com edificações ecléticas no final do século XIX e início do século XX. No interior do Estado de São Paulo, o mesmo fenômeno ocorreu em cidades cuja base econômica fosse o café. A cidade de Jaú é um dos inúmeros casos desta ocorrência. 


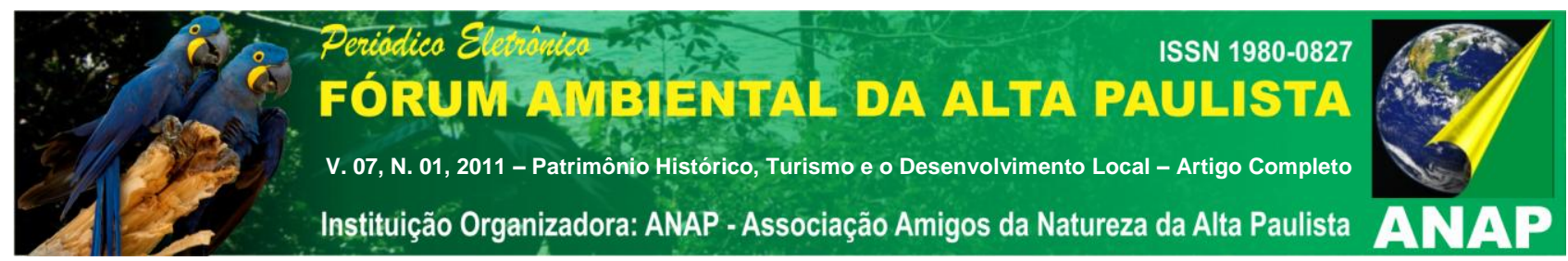

A arquitetura eclética não foi inicialmente valorizado pelo projeto preservacionista do governo federal, mas será que este período da história tem menos valor que as construções edificadas durante o período colonial e parte do Império? O fato é que maior parte de construções ecléticas é protegida por institutos ou conselhos nas esferas estaduais e municipais. São raros os casos de arquitetura eclética protegidos pelo governo federal. No entanto, elas podem ser atrativos turísticos como são as de arquitetura tradicional.

Este artigo tem objetivo discorrer sobre o caso da cidade de Jaú no interior paulista, abordando a evolução das leis de preservação locais, a tentativa do poder público tornar o sítio histórico em atrativo turístico e as experiências de propriedades rurais que já transformaram seus patrimônios em produtos turísticos. O referencial teórico foi baseado em bibliografia especializada, dissertação de mestrado, periódicos locais e programas educativos das fazendas.

\section{A CONSTRUÇÃO DO PATRIMÔNIO}

A cidade de Jaú, localizada no centro-oeste paulista, foi fundada em 1853. A região teve como início de povoamento um entreposto que servia para os navegadores do Rio Tietê se abastecerem em suas longas jornadas em direção ao Mato Grosso e Goiás no século XVIII, e alcançou seu apogeu econômico com a cultura cafeeira na década de 1920.

A primeira plantação de café registrada no município ocorreu no Bairro do Banharão em 1846. A partir desta data o café foi aos poucos conquistando novas áreas e teve este processo acelerado nos anos 1870 com a aproximação da ferrovia representada pelas construções dos terminais de Campinas e posteriormente de Rio Claro. A linha de ferro chegou ao município somente em 1887 concomitantemente ao aumento do fluxo de imigrantes europeus que vinham trabalhar nas fazendas café e abolição de escravidão. A soma destes acontecimentos resultou em um rápido crescimento econômico, acesso a novos estilos de vida e modos de construção. 


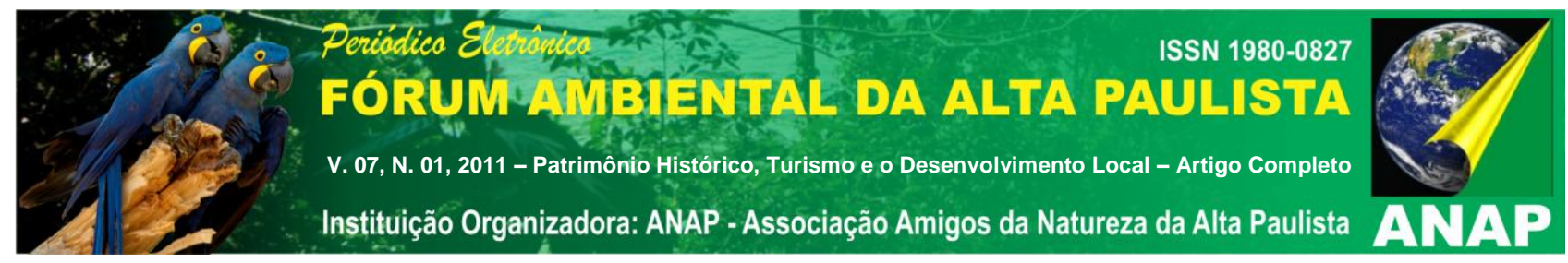

A vila acanhada cujas edificações eram feitas de taipa e de arquitetura tradicional foi substituída por construções de alvenaria de tijolo e decoradas com elementos arquitetônicos ecléticos. O mesmo aconteceu com as propriedades rurais do município, que foram adequadas ao cultivo do café e tiveram suas infraestruturas construídas em estilo eclético. Atualmente o município possui 492 edificações entre prédios comerciais, casarões e armazéns urbanos protegidos por lei municipal de preservação do patrimônio. Embora a agricultura tenha sido a base da prosperidade local o poder público não possui inventário e nem mecanismos de conservação de imóveis rurais.

\subsection{LEIS E DECRETOS}

A preocupação com a preservação do patrimônio cultural da cidade de Jaú

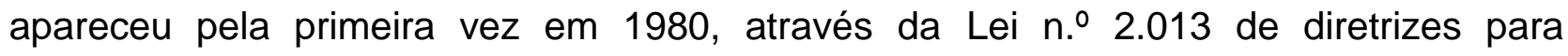
conservação do patrimônio histórico e arquitetônico de autoria do prefeito Alfeu Fabris, que tinha como objetivo o tombamento de bens, móveis e imóveis, cuja conservação fosse de interesse público em razão de seu valor estético ou histórico. Neste instante, o poder executivo deu o primeiro passo para que o patrimônio arquitetônico construído durante o ciclo do café na cidade tivesse alguma possibilidade de ser mantido para as próximas gerações. Após dezessete anos (1997), o prefeito Paulo Sérgio Almeida Leite sancionou a lei no 3.195 que tinha como objetivo a proteção da flora localizada em lugares públicos e tombamento de espécimes vegetais que justificasse a medida pelas condições de raridade, antiguidade, interesse histórico, científico ou paisagístico. Neste caso, esta segunda lei amplia a possibilidade de preservação da memória da cidade, não a concentrando somente no patrimônio edificado, mas no imaterial, na paisagem criada pelos cidadãos locais.

Até o ano de 1998, as leis de preservação não ofereciam nenhum tipo de incentivo econômico para os proprietários de imóveis passíveis de preservação. No entanto, outra lei de № 3.413 para a preservação foi proposta pelo vereador Marcelo de 


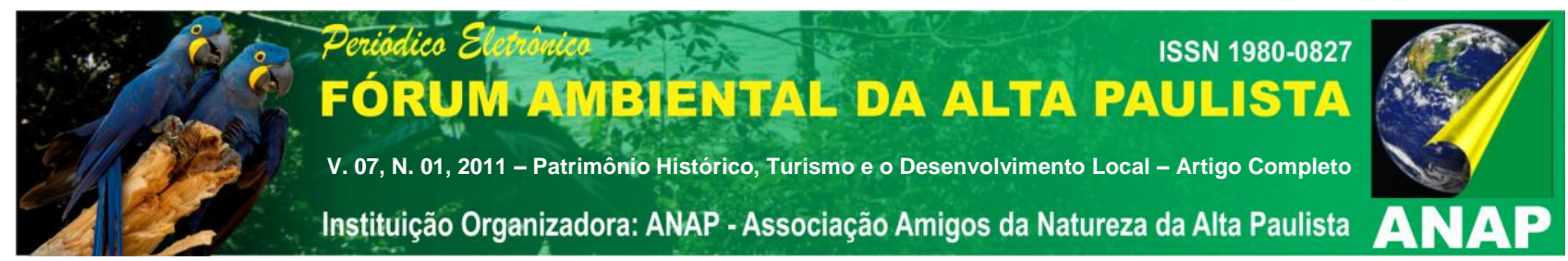

Karam Téio Curi para preencher esta lacuna em 1999. O poder executivo passou isentar os proprietários de pagamento de $50 \%$ no valor total do IPTU para imóveis de interesse histórico. Após 19 anos da primeira ação preservacionista, faltava ao poder público um mecanismo de inibição ou de critérios para definir quais imóveis não poderiam ter intervenções ou serem demolidos. No ano de 2001, o vereador José Carlos Zanatto propõe uma lei para disciplinar as demolições de prédios passíveis de preservação (Lei no 3.612). Nesta lei todo projeto de demolição de imóvel preservável deveria ser submetido à análise da Secretaria de Obras, que ao verificar tratar-se de edificação cuja preservação devesse ser assegurada, notificaria o proprietário da obra, para que se abstivesse de dar início à demolição.

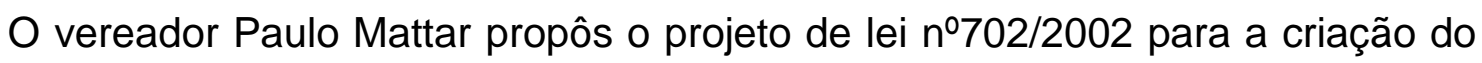
Conselho de Preservação Cultural do Município de Jaú, 23 anos após a edição da primeira lei de cunho preservacionista,. O conselho, no entanto, só seria criado por Decreto Lei oㅜ 3.833 de 09 de dezembro de 2003 do prefeito João Sanzovo Neto. O Conselho de Preservação do Patrimônio Cultural do Município de Jahu é um órgão colegiado de caráter consultivo e deliberativo, encarregado de representar a comunidade e assessorar o Poder Público Municipal em assuntos referentes à preservação do patrimônio cultural do município. Entre os conselheiros estão representantes do sindicato dos comerciantes, engenheiros e arquitetos, proprietários de imóveis preserváveis, ambientalistas, poder público, organizações não governamentais atuantes na cultura e assistência social, Ordem dos Advogados do Brasil e outros.

\subsection{O PATRIMÔNIO E O TURISMO}

Podemos indagar a razão de preservar edificações antigas quando estas são desvalorizadas por não atenderem as demandas comerciais ou habitacionais da atualidade. $O$ arquiteto Carlos Lemos (2006) nos ajuda a compreender o motivo para a preservação. 


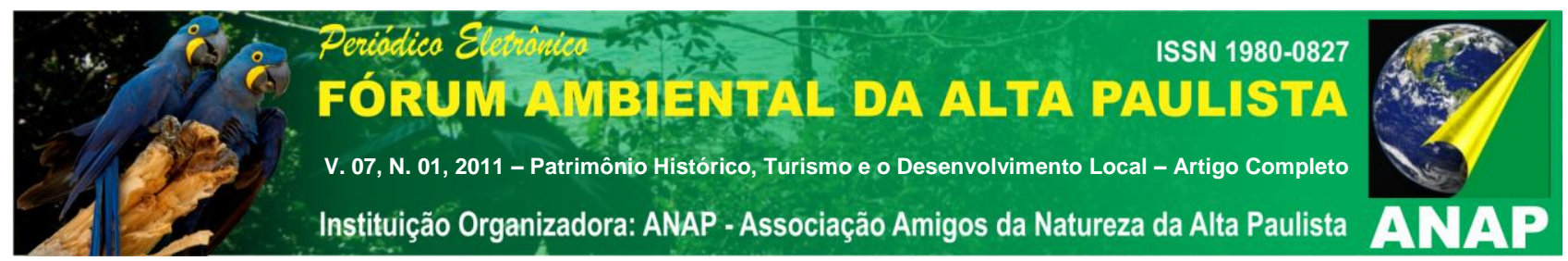

"É fácil entender que de uma determinada condição ambiental, e não existem duas iguais no mundo, e de um determinado povo, seja misturado da maneira como for, como o nosso, só pode resultar em um processo cultural cuja evolução sempre percorre diretrizes identificadas por uma linha mestra do saber predominante. Do saber as coisas, do saber fazer, do modo de pensar prevalente. É a definição de uma nacionalidade, cuja memória está justamente alinhavada ao longo de sucessivas transformações e evoluções havidas lentamente através dos tempos, devido tanto progresso tecnológico e seus meios de comunicação como aprimoramento intelectual e, também, aos facilitados contatos entre povos diferentes, estando nessa miscigenação o centro maior de interesse da compreensão do que seja patrimônio cultural de uma nação de populações algo diferenciadas como ocorre no Brasil... Preservar é manter vivos, mesmo que alterados, usos e costumes populares. É fazer também levantamentos, levantamentos de qualquer natureza, de sítios variados, de cidades, de bairros, de quarteirões significativos dentro do contexto urbano...Devemos, então, de qualquer maneira, garantir a compreensão de nossa memória social preservando o que for significativo dentro do nosso vasto repertório de elementos componentes do Patrimônio Cultural. (LEMOS, 2006 p.25, 26 e 29)

A arquitetura é parte deste repertório diverso. Ela reflete o gosto e o poder econômico do período que foi edificada. É um pedaço da história estático esperando novas leituras, interpretações e usos. Transformar o legado de 492 construções urbanas e algumas dezenas de sedes de propriedades rurais em algo economicamente viável é um desafio a ser vencido pelos proprietários e governo. Maria Lucinda Fonseca (2001) comenta que patrimônio e turismo é uma combinação recente.

A noção de patrimônio como recurso para o desenvolvimento é uma construção recente e está intimamente associada à especificidade que lhe permite fazer do espaço onde se localiza um lugar diferente de 


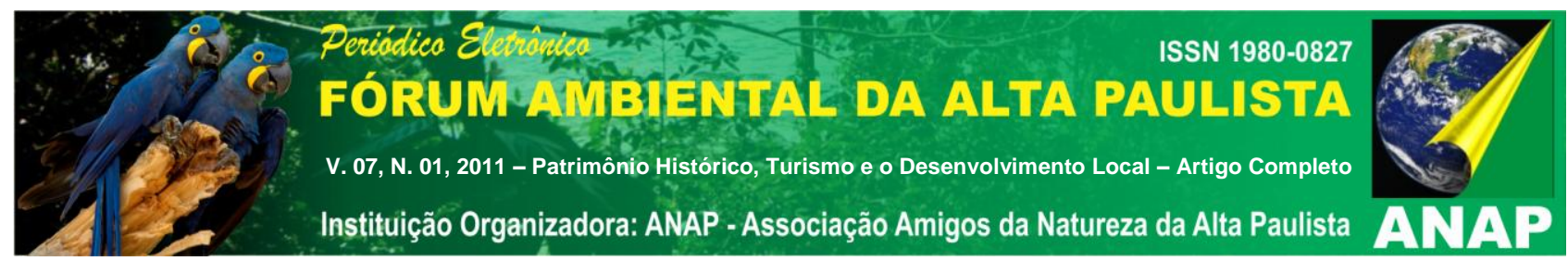

todos os outros, transformando-o numa atração turística que combina elementos tão diferenciados como a arquitetura, 0 artesanato, a gastronomia, as festas, as crenças, os modos de vida tradicionais e outros bens não materiais que lhe estão associados, ensejando a experiência da descoberta, de exotismo, de auto realização e de evasão do cotidiano (FONSECA, 2001 p.48)

O governo municipal, dos anos 2001 a 2008, foi o que instituiu a classificação de graus de preservação, criou o Conselho de Preservação do Patrimônio Cultural e reforçou o conjunto arquitetônico existente na cidade de Jaú como produto turístico. Ao imprimir material de divulgação do município dando enfoque no patrimônio natural e edificado nas zonas urbana e rural, o governo municipal mostrava que a preservação do casario eclético e remanescente de vegetação primária poderia render dividendos para seus proprietários e ao mesmo tempo manter parte da histórica local. Neste período houve vários exemplos de construções comerciais na área central adaptadas a novos usos e que souberam manter suas fachadas em estilo eclético. Os proprietários tiraram proveito da arquitetura para criarem um espaço com um visual diferenciado das demais construções contemporâneas.

O autor Clerton Martins (2006) descreve que o patrimônio cultural em si não é suficiente para a condição de se considerar um lugar especial. O simples fato do município de Jaú ter criado condições de preservação de seu conjunto arquitetônico não o torna em produto atraente para o turismo. O que fará com que as construções históricas locais se diferenciem de outras será "o conjunto de significados, os símbolos que a cultura local imprimiu nele, e é isso que leva o outro a sentir, partindo de seus valores, o lugar que se visita" (MARTINS, 2006 p.39). Uma vez que o significado da cultura local impresso nas construções de Jaú já foi descoberto pelo poder público com a confecção de material de divulgação com enfoque turístico, Martins complementa 


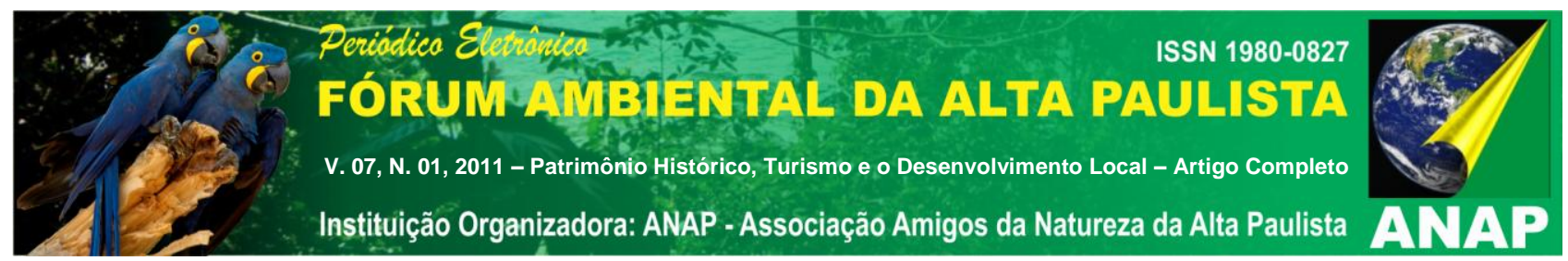

O que interessa ao fenômeno do turismo são aspectos mais peculiares de cada lugar, é o caráter mais autêntico de sua gente e seu cotidiano mais original, representado por toda sua gama simbólica, ainda que possa parecer estranho à estética da globalização. (MARTINS, 2006 p.46)

O aspecto peculiar do centro de Jaú constituído de casarões, casas comerciais, jardins e de uma igreja matriz notável é que os cidadãos locais habitam, trabalham e se divertem garantindo autenticidade ao produto turístico. É um espaço verdadeiramente usufruído pelos locais e não fachadas de um cenário estático. 0 mesmo ocorre nas duas fazendas que trabalham com turismo rural. $\mathrm{Na}$ busca por transformar o patrimônio cultural da cidade em atrativo turístico, podemos lembrar que 0 Fórum UNESCO de 1996 "diz que a memória é o motor fundamental da criatividade. Tal afirmação aplica-se tanto aos indivíduos quantos aos povos que encontram em seu patrimônio natural e cultural, material e imaterial os pontos de referência de sua identidade e as fontes de inspiração”.(CARNEIRO, 2006 p.19). Mário Beni, especialista em turismo salienta a importância do crescimento sustentável e defende que

"O modelo de desenvolvimento mais apropriado é o desenvolvimento endógeno. 'Por meio de mobilização social, participação comunitária, empreendedorismo para gerar a inclusão social e, conseqüentemente, o desenvolvimento da economia local'... outra matéria prima para o turismo é a preservação do patrimônio histórico e cultural, além da capacitação profissional" (BENI, 2009.)

A Jahutur, uma associação de comerciantes e prestadores de serviços, fundada em outubro de 2009, agrega estabelecimentos do trade turístico tais como: bares, restaurantes, hotéis, pousadas, agência de turismo, supermercados, agências de propaganda, casas noturnas, centros comerciais, hospitais, lojas varejistas e locadoras de veículos. A intenção era tornar essa associação de iniciativa privada em um 


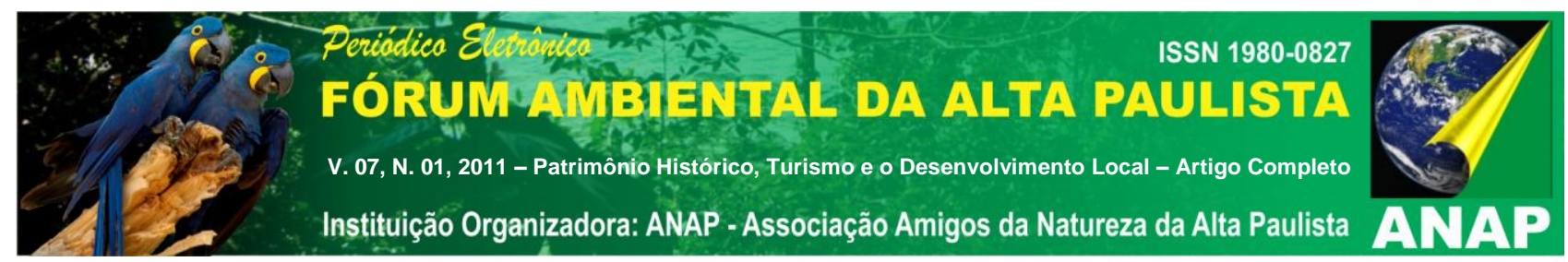

instrumento para a promoção da cultura e para preservação do patrimônio histórico e artístico da cidade (LOTTO, 2009). O presidente da associação Jahutur, Carlos Henrique Paes de Barros, é o responsável pela feira varejista de calçados, Jaú Trend Show, que ocorre duas vezes ao ano e faz os lançamentos do setor calçadista local. No quesito turístico é justamente o setor calçadista o melhor organizado e que atrai cerca de 60.000 visitantes ao município por mês, segundo o estudo promovido pelo turismólogo Fernando Figueiredo para a Secretaria Municipal de Cultura e Turismo de 2005 a 2008. Os "profissionais ligados à rede hoteleira da cidade são unânimes em dizer que o turismo de negócios é o que movimenta o setor em Jaú, com destaque para os centros de compras de calçados" (DONATO, 2011). No entanto, a maior parte dos visitantes da cidade fica restrita aos centros comerciais de calçados que estão localizados próximos às rodovias, não permanecendo mais que algumas horas no município. "O diretor da Jaú Trend Show, Paes de Barros, também percebe que os visitantes simpatizam com a cidade e seu patrimônio histórico, mas reclamam da falta de infraestrutura e de informações" (DONATO, 2011).

O Secretário Municipal de Cultura e Turismo de Jaú de 2009 a janeiro de 2011, André Galvão de França instituiu um calendário de eventos culturais que poderia se tornar em atrativo turístico para complementar o patrimônio histórico e turismo de compras. Foi durante sua gestão que foram confeccionadas e colocadas placas de sinalização com padronização internacional em toda a cidade, destacando os equipamentos culturais e turísticos (GALVÃO, 2011). Mas ainda o patrimônio histórico não consegue ser um atrativo maior no setor turístico da cidade, embora haja experiências bem sucedidas que o exploram como atrativo turístico cultural.

Na zona urbana, a Secretaria Municipal de Cultura e Turismo encampou as visitas guiadas de maneira informal pelo pesquisador em história, Júlio Poli, em 2010. As visitas são feitas no cemitério local e igreja matriz Nossa Senhora do Patrocínio. O objetivo do passeio ao cemitério municipal é a de observação da arte cemiterial e trajeto histórico de seus cidadãos. Já a visita ao templo católico tem como propósito identificar simbolismos e apreciar a arquitetura litúrgica. 


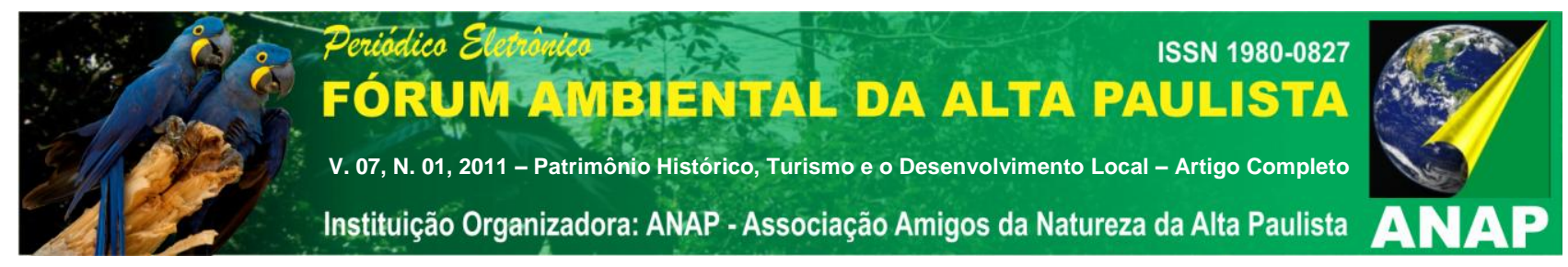

\subsection{EXPERIÊNCIAS DE TURISMO CULTURAL NA ZONA RURAL}

Vimos que o turismo cultural no centro da cidade ainda acontece de maneira esporádica e só foi encampada pelo poder público num passado recente. No entanto, as experiências com turismo na zona rural aconteceram desde década de 1990, sem a participação direta do governo local.

A Fazenda Santo Antonio dos Ypês, aberta no início do século XX, começou seu projeto de Educação Ambiental aproveitando o remanescente de mata nativa da propriedade preservada denominada Reserva Ecológica Amadeu Botelho em 1998. A reserva possui uma área de 190 hectares formada de uma floresta estacional semidecidual, com 169 espécies arbóreas, 24 espécies de mamíferos e mais de 100 espécies de pássaros. O Projeto Curumim foi desenvolvido para explorar esta área e tem como objetivo trabalhar a Educação Ambiental com as escolas, buscando despertar nos alunos a visão dos problemas ambientais e estimular o interesse pelo ambiente equilibrado e preservado. A reserva possui um centro de Educação Ambiental onde são feitas as palestras antes do passeio e servido lanche após a caminhada. (PROJETO CURIMIM, RESERVA ECOLOGICA AMADEU BOTELHO, 2006)

$O$ roteiro da visita se inicia com uma caminhada de 5 quilômetros pela mata com duas nascentes, passando por culturas de café, goiaba, limão e pêssegos. Neste momento os alunos são convidados a refletir sobre as diferenças entre o ambiente natural e o cultivado. A trilha termina em uma pequena cachoeira onde tomam banho e fazem piquenique. Na volta os alunos vão caminhando por dentro do leito do riacho, cuja lâmina de água é pouco espessa, fazendo a observação da mata ciliar, fauna e flora locais. Ao retornar ao Centro de Educação Ambiental é servido um lanche e para finalizar a visita ao viveiro de mudas. Embora a fazenda Santo Antonio dos Ypês possua sede e toda a estrutura de secagem e estocagem de café preservadas e em funcionamento, os proprietários não as utilizam como atrativo turístico. 


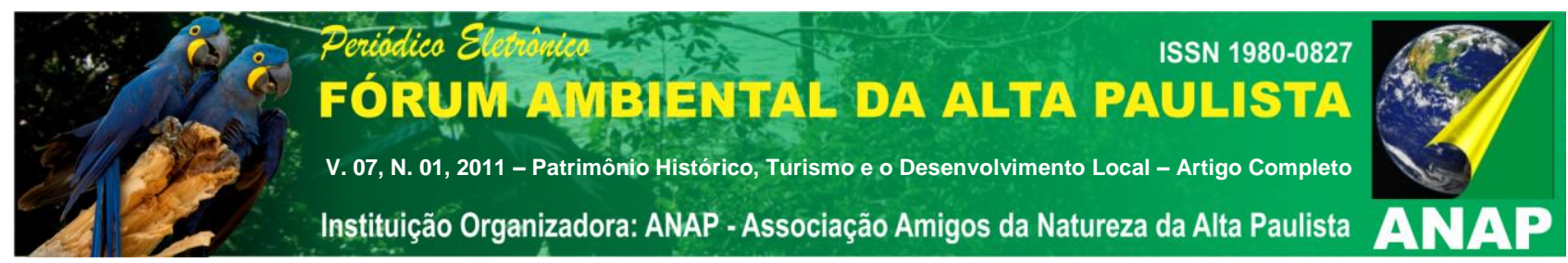

A Fazenda Mandaguahy, aberta em 1858, começou seu programa educativo em 1997, explorando inicialmente somente a paisagem campestre como local de lazer. Ainda no mesmo ano recebeu os primeiros grupos de um curso livre de Educação Ambiental. Os primeiros espaços a serem visitados pelos turistas eram áreas onde 0 meio natural prevalecia. As atividades de lazer aconteciam no pomar de jabuticabeiras ao lado da sede. Já os estudantes do curso de Educação Ambiental caminhavam pela mata ciliar e aproveitavam o córrego para a prática de bóia-cross, ou seja, descida do leito flutuando com bóias. Aos poucos outros espaços foram sendo adequados à visitação e incorporados ao roteiro.

A propriedade possui a maior parte de suas construções originais preservadas e uma área de mata secundária. Sede, parte do terreiro de secagem, tulha, casa do administrador, colônia e senzala formam o patrimônio edificado da fazenda e foram incorporados ao roteiro de visitação como parte do programa educativo. O mesmo aconteceu com a trilha do bosque que foi aberta em uma área de mata secundária.

Se a Fazenda Santo Antonio dos Ypês optou por explorar somente seu patrimônio natural a Fazenda Mandaguahy resolveu desenvolver um programa educativo que contemplasse os dois. Como já foi citado, a elaboração dos programas educativos e recreativos foi desenvolvida conforme surgia uma nova necessidade ou o local era recuperado e adequado para a visitação. Atualmente a Mandaguahy mantém cinco possibilidades de programas educativos que na verdade possuem como base a visitação ao patrimônio edificado e natural, mas com diferentes ênfases de aprofundamentos.

O primeiro programa denominado Bosque Maria Cecília enfatiza a percepção do meio natural através da identificação das espécies e o papel desempenhado por elas na dinâmica da vida na mata, bem como aprender como as árvores protegem desde as nascentes e cursos de água até a estação de captação de água de distribuição na área urbana. $\mathrm{Na}$ trilha os visitantes podem trabalhar a percepção de diferentes texturas do relevo e perfumes. O bosque também é apropriado para atividades de ciências, biologia e geografia. Uma variedade de plantas nacionais e exóticas, tipos de solo variados 


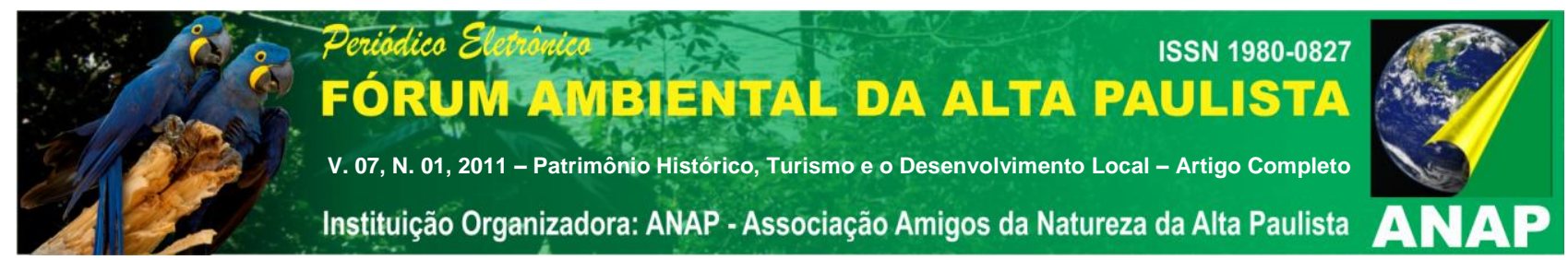

(argiloso estruturado, arenoso e humoso), água rica em minério de ferro, quartzos coloridos. O passeio pode durar até uma hora.

O segundo programa, Ciclos Econômicos, propõe uma reflexão sobre os diferentes ciclos produtivos vivenciados pela região desde o início de seu povoamento e as marcas deixadas por eles na arquitetura e modo de vida. $O$ texto abaixo explicita melhor a proposta.

O tema Ciclos econômicos traça uma linha histórica econômica através de um passeio dirigido pelas edificações, jardim e pomar preservados da fazenda. O roteiro contempla a organização social do universo rural cafeeiro por meio de questionamentos de quem eram os habitantes da propriedade, do uso e localização das edificações durante 0 ciclo do café e canavieiro. (VALENTE, 2010 p. 177)

A Educação Ambiental é um tema recorrente em todos os programas anteriores, no entanto, o enfoque maior é dado no programa de mesmo nome. O objetivo é a compreensão dos ciclos de vida e a interatividade homem e meio natural. Também é feita uma reflexão de como o homem é um agente modificador do meio natural e suas conseqüências. O programa inclui passeios pelo jardim com plantas nacionais e exóticas, plantações orgânicas, mata ciliar e quando requisitado, uma oficina de brinquedos de jornal e garrafa PET.

Da mesma forma que o tema sobre o meio ambiente natural é recorrente, a Educação Patrimonial permeia todos os outros programas. No programa com denominação de Educação Patrimonial há ênfase no papel do homem como agente modificador do ambiente natural através dos testemunhos representados pelas edificações existentes na propriedade. O objetivo do programa é refletir sobre como as características do meio natural permitem o surgimento de determinadas atividades econômicas ou culturais e suas conseqüências para o meio natural. As reflexões são feitas através de atividades lúdicas como exploração arqueológica nas ruínas da antiga colônia de imigrantes e na descoberta de costumes dos moradores da Casa Grande. De 


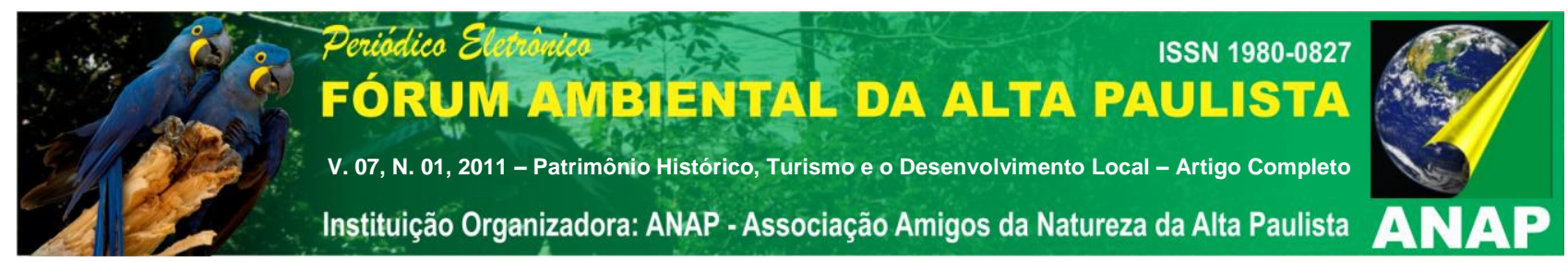

acordo com a proposta compreender o modo de vida de nossos antepassados propicia um melhor entendimento de quem somos.

O último programa é dedicado ao ciclo da água. Este programa acontece com visitas complementares à segunda estação de captação e tratamento de água de Jaú, ETA II, e às áreas de preservação permanente da Fazenda Mandaguahy. O projeto ciclo das águas propõe conscientizar os visitantes da importância do uso racional deste recurso natural, mostrando desde áreas destinadas a preservação permanente, onde olhos d' água brotam do solo, captação e tratamento para uso doméstico.

Um traço comum aos programas educativos das Fazendas Santo Antonio do Ypês e Mandaguahy é o uso de roteiros interpretativos. Segundo Stela M. Murta e Brian Goodey, "interpretar é um ato de comunicação. Pode-se dizer que interpretar é a arte de comunicar mensagens e emoções a partir de um texto, de uma partitura musica, de obra de arte, de um ambiente ou de expressão cultural" (2005 p.13).

Ao analisarmos a descrição das atividades educativas propostas pelas duas propriedades rurais as mensagens sobre a necessidade de cuidar dos meios natural e construído estão relacionados à criação de emoções nos visitantes.

A Fazenda Santo Antonio dos Ypês ao levar seus turistas à mata causa nos visitantes a sensação de estar experimentando a descoberta da floresta repleta de mistérios, sons, perfumes e texturas diferentes. A possibilidade de se avistar animais silvestres mexe com o imaginário. Ao longo da trilha há placas indicativas das diferentes espécies existentes e de cautela com enxame de abelhas. Ao sair da trilha passando pelas plantações comerciais o visitante sente a diferença da temperatura entre uma área com árvores de copas altas para a área cultivada. As recompensas estão por vir com o banho de cachoeira e caminhada no riacho. A interpretação nesse caso é toda voltada para as sensações prazerosas e belezas proporcionadas pela preservação da mata primária.

$\mathrm{Na}$ Fazenda Mandaguahy a interpretação tem ênfase na "arte de revelar in situ o significado do legado natural, cultural ou histórico, ao publico que visita estes lugares em seu tempo livre" (MURTA e GOODEY, 2005 p.14). A exploração da emoção é usada 


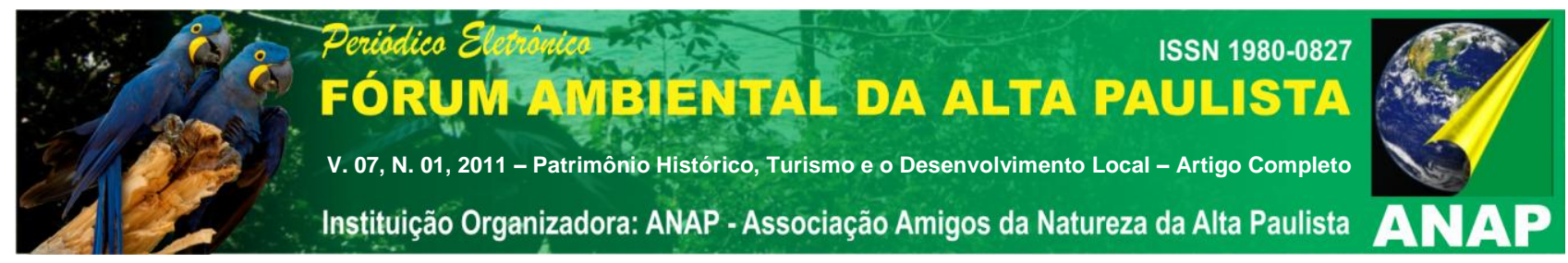

da mesma maneira que na Santo Antonio do Ypês. Entrar em construções históricas, sentir a opressão de ambientes sem janelas como as senzalas, circular pela sede decorada com móveis e objetos de época pode causar diferentes reações por serem locais tão próximos, mas de realidades tão distintas. O mesmo prazer de descobridor ou pioneiro sentido pelos visitantes da Santo Antonio dos Ypês ao visitar a Mata Amadeu Botelho pode ser experimentada pelos turistas que passeiam na área reservada a família no entorno da sede. Talvez a curiosidade em penetrar em um local antes restrito seja maior que o sentimento de descoberta. Murta e Goodey (2005) observam que num mundo onde o padrão de desenvolvimento é mais destrutivo do que preservacionista

a única chance de reverter esse quadro que temos hoje é trazendo a preservação para o coração e a mente das pessoas, lidar com suas emoções de forma a desenvolver nelas afeição pelo ambiente que as circunda, pelo espaço público, pela natureza, pela vida silvestre e por sítios históricos (MURTA e GOODEY,2005 p.17)

Maria de Lourdes Horta (1999) complementa o processo de afeição pelo ambiente proposto por Murta e Goodey, escrevendo que

- conhecimento crítico e a apropriação consciente pelas comunidades de seu patrimônio são fatores indispensáveis no processo de preservação sustentável desses bens, assim como o fortalecimento dos sentimentos de identidade e cidadania. (HORTA et Al, 1999 p.06)

A Prefeitura Municipal de Jaú implantou nas escolas municipais o Projeto de Educação Patrimonial em 2010. As Secretarias Municipais de Educação e a de Cultura e Turismo desenvolveram um projeto de Educação Patrimonial para alunos do $4^{\circ}$ ano do ensino fundamental. A autora do projeto Maria Luisa Toledo Pelegrina e o supervisor Guilherme E. A. P. de Castro Valente têm como intenção divulgar principalmente o patrimônio edificado do município através de atividades ministradas pelos professores de 


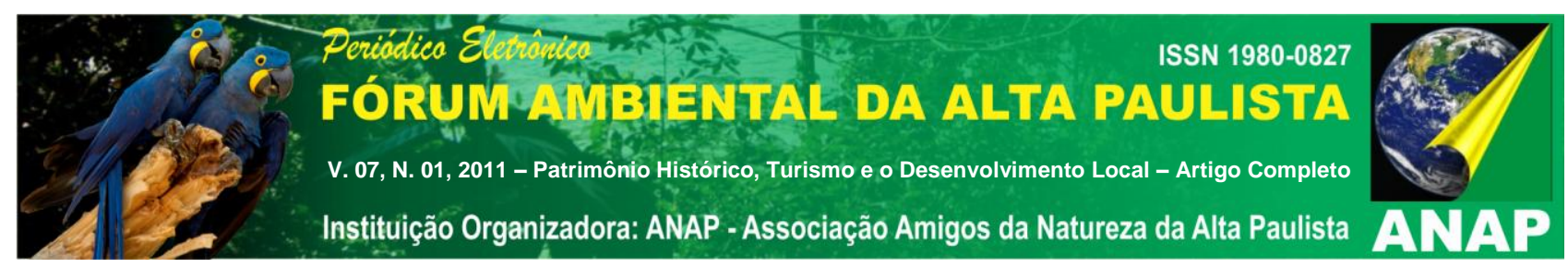

educação básica e de Arte da rede pública. Os alunos são apresentados a um breve histórico e características gerais da arquitetura eclética através de explanações e visita guiada pelo sítio histórico. A exposição ao patrimônio propicia reflexões sobre quem o construiu e habitava nas edificações. Como finalização os alunos produzem painéis com suas interpretações do patrimônio local como forma de apropriação e afeição aos bens pesquisados. O despertar do sentimento preservacionista é o principal objetivo das iniciativas de turismo cultural urbano e rural existentes na cidade de Jaú. A afeição pelo patrimônio natural e edificado do município será o alicerce para sua preservação e conservação.

\section{CONCLUSÃO}

Podemos verificar que houve um processo longo de criação de mecanismos para a preservação de bens imóveis de valor histórico ou arquitetônico no município de Jaú. Foram mais de 20 anos até que fosse assegurada a manutenção deste sítio histórico. Notamos também o esforço do poder público em divulgar e tornar este patrimônio num diferencial para os proprietários e cidadãos. Constatamos que embora não haja mecanismos de preservação que contemplem o patrimônio da zona rural, foi justamente nela onde ocorreram as primeiras ações bem sucedidas de transformação do patrimônio natural e edificado em produto de turismo cultural. A implantação do projeto de Educação Patrimonial na rede pública de ensino fundamental foi outro passo importante, talvez o mais importante de todos, pois ele permite a descoberta e apropriação do patrimônio histórico local pela população jovem, tornando-os guardiões e futuros visitantes deste tipo de atrativo. A formação de público consciente de seu papel na preservação da história e consumidor de turismo cultural é a garantia de manutenção de bens de valor histórico cultural financiados pelas taxas de visitação e serve de incentivo para outros empreendedores cuidarem de seus imóveis históricos ou bens naturais. 


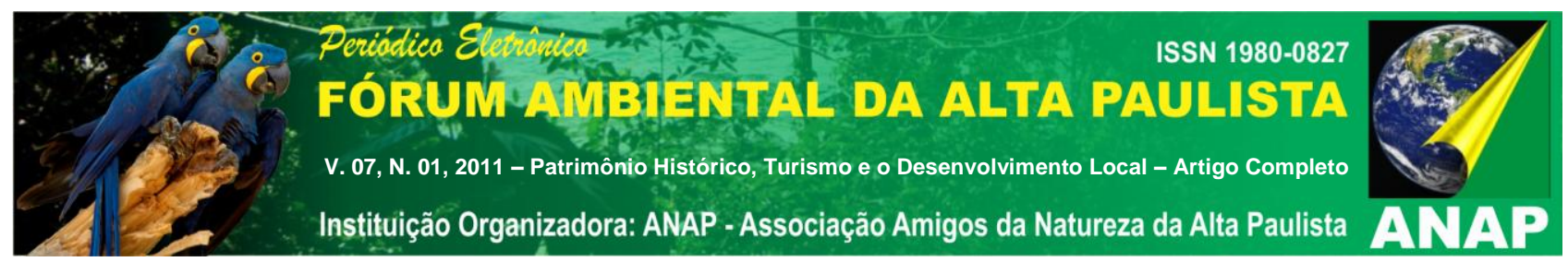

\section{REFERÊNCIAS}

BENI, Mário in Jornal O Comércio do Jahu. Jaú, 10/12/2009

CARNEIRO, Henrique F. Banalização do Patrimônio cultural material e conseqüências perversas para a vida na cidade in MARTINS, Clerton (Org.). Patrimônio Cultural: da memória ao sentido do lugar. São Paulo: Roca, 2006

DONATO, Priscila in Jornal O Comércio do Jahu. Jaú, 16/10/2009

FONSECA, Maria Lucinda. Patrimônio, turismo e desenvolvimento local in RODRIGUES, Adyr Balastreri (Org.) Turismo rural: práticas e perspectivas. São Paulo: Contexto, 2001 p. 48

GALVÃO, A. Carta ao Leitor in Jornal O Comércio do Jahu. Jaú, 21/05/2011 HORTA, Maria de Lourdes P. et Al. Guia prático de Educação Patrimonial. Brasília: Instituto do Patrimônio Histórico e Artístico Nacional, Museu Imperial, 1999. p.6.

LEMOS, Carlos A. C. O que é patrimônio histórico. São Paulo: Brasiliense, 2006 LOTTO, Vera. Psiu in Jornal O Comércio do Jahu. Jaú, 16/10/2009

MARTINS, Clerton. Patrimônio cultural e identidade: significado e sentido do lugar turístico in MARTINS, Clerton (Org.). Patrimônio Cultural: da memória ao sentido do lugar. São Paulo: Roca, 2006

MURTA, Stela. M. e GOODEY, Brian. Interpretação do patrimônio para visitantes: um quadro conceitual in MURTA, Stela M. e ALBANO, Celina (org.) Interpretar o patrimônio: um exercício do olhar. Belo Horizonte: Ed. UFMG; Território Brasilis, 2002 Projeto Educativo e Recreativo Fazenda Mandaguahy. Jaú, 2011

Projeto Curumim - Reserva Amadeu Botelho. Jaú, 2006

VALENTE, Guilherme E. A. P. C. Mudança e permanência: quatro gerações e a propriedade rural no município de Jahu. Araraquara: Dissertação de Mestrado em Desenvolvimento Regional e Meio Ambiente - UNIARA, 2010 